\title{
The Political Economy of Gas, Soy and Lithium in Morales's Bolivia
}

\author{
Nicole Fabricant and Bret Gustafson \\ Towson University / Washington University in St. Louis
}

\begin{abstract}
Bolivia has accomplished some of its goals since Evo Morales was elected president in 2006. It has made advances in expanding inclusion for indigenous peoples and reducing levels of poverty. They have expanded services and infrastructure for the poor and prioritized long-abandoned rural areas. Middle class has grown by more than $10 \%$ and both government and the economy have tripled in size. Yet Bolivia remains deeply embedded in extractivist economics. This piece looks at the relationship to global trade and the political paradoxes that gas drilling, soy production and mineral extraction create for the country. Export-oriented dependency have had predictable effects on labor relations, policy planning, and most significantly the lives of people on the ground.
\end{abstract}

\section{Keywords}

Export-oriented dependency, extractivist economy, gas, lithium, soy 


\section{Resumen}

Bolivia logró algunos de sus objetivos desde que fuera elegido presidente Evo Morales en el año 2006. El país hizo importantes avances en cuanto a la inclusión de los pueblos indígenas y la reducción de la pobreza. Se ampliaron los servicios y la infraestructura para la gente pobre y se priorizaron áreas rurales abandonadas durante años. La clase media creció más de un diez por ciento y tanto el gobierno como la economía se triplicaron en tamaño. Aun así, Bolivia continúa profundamente implantada en una economía extractivista. Este trabajo analiza la relación entre el comercio global y las paradojas políticas que la perforación de gas, la producción de soya y la extracción de minerales crean en el país. La dependencia de las exportaciones ha tenido efectos predecibles en las relaciones laborales, la planificación de políticas y, lo más importante, en la vida de la gente común.

Palabras claves

Dependencia de las exportaciones, economía extractivista, gas, litio, soya

\section{Introduction}

Bolivia over the past 14 years has accomplished some of its goals since Evo Morales was first elected in 2007. It has made significant advances in expanding inclusion for indigenous peoples and reducing levels of poverty. Bolivia has seen a notable reduction in terms of extreme poverty (which dropped nearly by half), tripling of minimum wage, and inclusion of indigenous peoples into important government positions. They have expanded services and infrastructure for the poor and prioritized long-abandoned rural areas. Middle class has grown by more than $10 \%$ and both government and the economy have tripled in size.

Yet Bolivia remains deeply embedded in extractivist economics. In this short piece--parts of which have been excerpted-from an earlier NACLA article, we look at the relationship to global trade and the political paradoxes that gas drilling, soy production and mineral extraction create for the country. Export-oriented dependency seem all too familiar and have had predictable effects on labor relations, policy planning, and most significantly the lives of people on the ground. Let's take a closer look at each of these areas: gas, soy and lithium. 


\section{Bolivia and Natural Gas}

Bolivian gas exports comprise the largest share of foreign trade, having risen from around five million cubic meters in 1995 to over 40 million cubic meters per year in 2016. The 2006 contract renegotiations that were referred to as a "nationalization" --whereby Morales created a more socially stable investment environment that had benefits for segments of the Bolivian population and for transnational investors-yielded a boom in the national treasury, with over 2 billion dollars in royalties in 2017, down from a high point of 5.5 billion in 2014. Most of the gas is exported to neighboring Brazil, a smaller share goes to Argentina, and the rest (around 10 percent) is for domestic consumption. The government has made great strides in expanding access to gas in urban areas at low prices, helping to legitimize (or obscure) the fact that most of the country's gas resources are shipped out to fuel Brazilian industry. In turn, capital investments in gas come largely through Brazil-by way of Petrobras and its state and global investors-Capital also comes via Spain's Repsol, which operates the largest field supplying gas to Argentina. Formerly the owner of the Argentine energy company YPFB (Yacimientos Petrolíferos Fiscales Bolivianos), Repsol today operates much like an extension of the Argentine gas industry, returning gas to Argentine consumers and Repsol's own distribution and processing infrastructure. By the same token, Petrobras, state controlled but also traded on Wall Street, operates like an extension of the Brazilian gas industry. Petrobras distributes and sells Bolivian gas into its own extensive supply chain of public and privately held distributors, processors, and industrial plants. In this way, the rural outback of the Bolivian Chaco has become an energy supply field for the two largest economies in South America. A third major actor is France's Total, now operating the Incahuasi block in Santa Cruz, which is set to expand extraction in coming years.

The Bolivian government itself is also reinjecting capital into the gas industry by way of its own national company, YPFB. The hope is both to expand the state's role in exploration -much of it contributing to conflicts over social and environmental rights- and in "industrialization" of the gas itself, mostly for plastics and fertilizer. This has included contentious, but ultimately successful, efforts to build gas processing plants in the department of Santa Cruz and in southern Bolivia. The state also speaks of contributing, along with hydropower and solar, to the creation of an energy export model, providing energy to industrial countries that surround it, particularly Brazil, Argentina, and Chile. 
The state's vision of industrialization is perhaps pragmatic, but it is also limited. Presumably, such efforts could deepen the country's reliance on manufactured imports of everything from household appliances to heavy machinery, from the very same countries that are the buyers of extracted resources.

In political terms, the economic expansion of access to gas for domestic consumers has been a boon to the Morales government. At least in urban areas and in the aspiring rural peripheries that are not impacted directly by the negative aspects of extraction, the more gas the better. Government spending at all levels -national, regional (departmental), and local (municipal)has increased thanks to the direct hydrocarbon tax, and royalties have been distributed to different entities (the military, state universities, pensions and cash transfer programs, new indigenous universities, and the corruptionplagued Indigenous Development Fund). While still somewhat regressive, the government has also sought to ameliorate its dependence on oil taxes and royalties by increasing domestic taxation and enforcement -particularly on income, consumption, and financial transactions. Government budgets at all levels have generated popular expectations about salary hikes, infrastructure investment, and increased spending on social services. However, the fulfillment of these expectations has become increasingly dependent on the present and future availability of gas revenues. In turn, such revenues are contingent upon external demand and high prices, as well as the continued availability of gas reserves themselves. Thus, the need for foreign investment in exploration has led to the deepening of neoliberal approaches. This includes the opening of protected areas to extraction and the weakening of citizen rights to shape, much less oppose, new drilling projects. For example, prior consultation (consulta previa), an indigenous right to have a say in development projects of any sort, has been legally weakened. Police repression of indigenous protest, though not widespread, has also occurred.

A second political consequence of intensified gas development has been the need to either attract foreign investment or take on foreign debt. The opposition has made much of China's growing role in the Bolivian economy, especially as a creditor. Yet it remains to be seen how Bolivia will continue to finance aspirations in the gas economy. At the end of the day, and notwithstanding myriad environmental and social concerns, the bottom line is that the country has chosen to maintain a strategy of capitalizing the country and encouraging consumer-based growth by accelerating the monetization of natural gas. 
The social structure of the gas industry in Bolivia mirrors that of gas industries globally: vertically divided between big operators and subcontracted service companies, with risk often assumed by the state. What's more, the entire operation tends to be heavy on capital and light on job creation, with a propensity to redistribute financial profits upward and toward urban managerial centers, far away from the extractive sites themselves. To obtain a job in the hydrocarbons industry is a common dream in the rural peripheries of Bolivia's gas region. Yet for rural peasant and indigenous dwellers, most forms of employment will never pass the level of machetero (the unskilled workers hired to clear bush for seismic exploration transects or other infrastructural operations) or albañil (plasterers hired for light construction). In reality, urban technicians and engineers from Santa Cruz do most of the well-paid work. In their blue denim shirt and jeans and heavy work boots they are easy to spot while passing through rural towns. Although many of these workers are nonunionized, plant workers and engineers enjoy a rather luxurious life in the rural gas plants. Laborers in the national company YPFB are unionized, but the last decade has seen virtually nothing in the way of labor mobilization for the simple reason that there are not enough unionized workers to have a major political impact, nor have there been significant grievances at that level. Rather, conflicts over labor are locally focused, as small communities vie for jobs for the unemployed, most often in temporary construction work or in the coveted contracts for food provisioning, or catering (the English word that has entered the jargon of the Bolivian gas industry). As one might expect, there is a gendered and racialized stratification to this entire pyramid. Even as the state has taken great strides to "indigenize" the public sector, in the gas industry the labor pyramid extends downward from the mostly male, and mostly lighterskinned urbanites of the corporate office to the mostly indigenous rural machetero, with most rural women accessing employment, if at all, as rural launderers or cooks.

The social and spatial form of gas production yields new consumption in urban centers and disrupted lives in rural gas enclaves, where the needs of gas - from water to labor to space to security $\neg$-impose themselves on existing lives and livelihoods. Truck and bus traffic increases and businesses, small and large, pop up to try to attract the relatively well-paid labor as consumers. Rising threats to water, both real and perceived, are increasingly at the epicenter of the environmental crisis. Rural communities, like the Guaraní, have become convinced that drought, dried waterholes, and dwindling streams are due to the impacts of exploration activity. Yet rural opposition is ameliorated by offers 
of small development projects or employment, invariably temporary, to community members. Meanwhile, rivers and streams are increasingly being tapped by the industry to provide water for drilling activities, even as toxic waste increases. Although the full impact of gas activities has yet to be adequately documented in environmental terms, there are sure to be rising conflicts in the drought-ridden Chaco. As part of the quest to expand Bolivia's reserves, there is now talk of fracking as a future possibility. If this comes to pass, there will surely be tension if and when the full hydrological dimensions of fracking are brought to public awareness. In sum, we might say that Bolivia's boom as the aspiring energetic heart of South America is built on both consumer dreams and less visible forms of slow violence.

\section{Bolivia and Natural Gas}

Santa Cruz, home to 60 percent of Bolivia's national soy yield, represents the powerful epicenter of the country's soy industry. At present, soy is Bolivia's third-largest source of foreign exchange (after gas and mining), representing 4.6 percent of GDP and 10 percent of total exports. Similar to gas, soy is a predominantly export-based commodity, which embeds Bolivia within webs of foreign capital and influence. Most of the production is exported within the Andean region -particularly to Chile, Ecuador, Peru, and Venezuela. However, unlike a portion of the revenue from gas -which supports public sector and social spending- soy production is predominantly subsidized by the Bolivian state. The state directs subsidies toward a narrow population of agribusinesses and urban-based landowners. The subsidy to diesel -still imported and still underwritten by the government- is crucial to the industry. In addition, since 2012, the MAS has made backroom deals with the eastern agrarian elite that virtually nullify any radical land reform that might limit large-scale latifundia landholdings. Brazilian and Cruceño (i.e. Santa Cruz-based) agribusiness elites control much of the soy production. Soy wealth, tied to capital investments from Brazil, Argentina, Peru, and Colombia, flows back out of the country again and is not re-invested into the national treasury. (As revealed in the Panama Papers, Bolivia's biggest soy king, Branko Marinkovic, now in exile for his alleged participation in a plot to overthrow Morales in 2010, stored much of his wealth elsewhere). Yet the MAS has largely made its peace with soy. Once virulent critics of the Morales government, like Gabriel Dabdoub, head of Bolivia's agro-industrialists' chamber of commerce, now tout government policy as bringing "good prospects." Due to the increased global demand for 
soy as animal feed and in biofuel production, particularly in China and the European Union, Morales announced in 2012 ambitious plans to boost the area of land under cultivation from 2.7 million hectares in 2015 to 4.5 million hectares by 2020 .

In political terms, the boom in soy has led to new alliances between the MAS and regional and transnational economic elites. The government has signed off on new credit facilities for big farmers and has retreated from its own denunciations of the rural elite. Peasant and smallholder land invasions and claims to rightful occupation of unused private lands- were strongly supported by the MAS as it rose to power. Such assertive land occupations are now virtually non-existent. Against the significant role of the state in gas and mining, governability has led to a détente with the agrarian elite in Bolivia's eastern departments. Despite the fact that the region's politicians, many of whom are deeply connected to Bolivia's rural elite, are still at the forefront of opposition to the MAS, they do so with a much tamer rhetoric than what existed in the mid-2000s.

In the agro-industrial east, one sees more clearly the workings of subimperial formations like that of the Brazilian ruralista class with its ties to São Paulo and to international financial capital. Since the 1980s, Brazilians, many of whom have deep ties to the soy business back home, became increasingly influential in Bolivia's soy industry. These Brazilians became fully integrated into local elite social circles, not only in the economic sphere but also in Cruceño politics promoting regional autonomy. Many Brazilian agriculturalists have even married into local families. And Brazilian soybean producers today even serve on the board of the National Association of Soybean Producers (ANAPO). As Bolivian land specialist Miguel Urioste noted in his 2012 study of the industry, today in Santa Cruz there is a consolidated agro-industrial Brazilian elite that holds a significant amount of power within governmental structures at the local, regional, and even national levels.

Bolivia's agribusiness elites have been collectively advocating and pressuring the MAS to remove all restrictions on GM soy. As Journalist Jimmy Langman reported for NACLA in volume 41(1) Latin American manufacturers produce and sell generic versions of monocrotophos (manufactured in China but packaged and sold cheaply to Bolivia). Soy producers emphasize the need to remove all restrictions on the use of biotechnology to increase productivity. Remarkably, a recent gathering of social movements has now also endorsed genetically modified seeds, another sign of the rapprochement between the MAS leadership sectors and agro-industry. Beyond GMOs and biotechnology, 
Brazilians, together with local Cruceño elites, have also been advocating for the removal of restrictions on exports. As it stands now, exporters are obligated to sell in the local market at "socially responsible" prices, which are frequently below production cost, until domestic demand is satisfied.

With respect to the social impacts of the soy, the industry is vertically integrated with global reach. Scholars Ben McKay and Gonzalo Colque (2016) have described the soy regime as a "soy complex," tracing the connections between the production of genetically modified seeds, chemical inputs, agricultural machinery, storage facilities, processing, transportation, and the financialization of the agro-food system. There is also a growing multitude of soy-based end products traded on the global market. This includes animal feed, edible oils, and industrial products, such as biodiesel. Technological advancement, mechanization and concentration of capital are putting a squeeze on labor. Cristóbal Kay has called this process "semiproletarianization," meaning small-scale landowners engage in wage labor activities and other rural, non-farm activities and employment while renting parcels of land to medium and large-scale farmers. One recent study by Bolivian land researcher Juan Pablo Chumacero has argued that in some cases, up to 30 percent of the rural population exists at a below-subsistence level because of lack of access to land.

For those farmers who own 50 hectares of land or less, it becomes increasingly difficult to compete as their access to capital and technology is limited. Further, industrialization of agricultural production and the widespread adoption of chemicals, like Monsanto's glyphosate herbicide, have displaced wage laborers. The soy complex in Santa Cruz is not generating as many jobs as it is erasing. Farmers who are not productive enough to compete in this industry migrate to city centers where the apparent urban boom tied to gas-fueled consumption seems attractive. But rural migrants often go from under-employment in the rural sector to under-employment in the urban sector. Structurally speaking, the current economic model may have already surpassed its capacity to absorb these populations. Urban and rural underemployment appears to be a more durable structural component of the extractive economy that reproduces broader patterns of exclusion. While movements like the Bolivian Landless Peasant Movement (MST-B) were a powerful alternative in the era of late 1990s and early 2000s, providing opportunities for collective ownership and small-scale agro-ecology, today MST-B is largely absent in and around Santa Cruz, incapacitated by the government's criminalization of land occupations. 
In terms of alternative visions of working the land, where does this leave us? Rebooting land reform -and policies to support small and medium-scale agriculture- are crucial if a more robust, inclusionary economy is to be built. Although the most extreme right-wing elements of the eastern elite, the marches, demonstrations and violence against highland indigenous people as spectacular acts claiming rights to land, resources, and departmental autonomy, seemed to calm by 2010-2011, the current pact between agrarian elites and the MAS means that not even the Bolivian state is positioned to challenge the political power of those members of the agrarian elite that remain.

Alongside labor displacements and demobilization of rural movements are the radical environmental shifts that have occurred as a result of largescale, hyper-mechanized soy. Change in land use over the last three decades, including the deforestation of much of the Amazonian region, has resulted in the loss of biodiversity and exhausted soil. Soil cannot rejuvenate itself after the monoculture production of soy, limiting the possibility for smaller-scale agriculture and ultimately national food sovereignty.

Beyond the socio-environmental consequences of large-scale soy are the health concerns that are linked to the increased use of agricultural chemicals and pesticides. All one has to do is look at neighboring Argentina and Paraguay to see what increased usage of chemicals like glyphosate has meant for community health. Studies there have shown links between the use of glyphosate, used in Monsanto's Roundup Ready, and several kinds of physiological malfunctions in both humans and animals, increased rates of cancers, miscarriages, and birth defects. These are perhaps the less visible violence of the economic boom that are associated with the soy economy, which slowly work their way into rural landscapes and bodies far from the booming urban centers.

\section{From Green Gold to Lithium Dreams}

If soy has come to represent a short-term economic growth strategy, linked largely to regional capital interests, Bolivia's mining industry has been seen as a longer-term economic project with an even more global reach, operating largely on an axis that runs from China to the U.S. and on to Europe. Tin, zinc, and silver are still flowing out of the Andes, and in many ways, foreign capital is still the largest beneficiary of these activities. Of late, the government has found itself in a bind, however, stuck between its desire 
to recreate the state mining company (COMIBOL) and workers' unions, on the one hand, and the country's powerful and independent "cooperatives" (groups of independent miners, neither in the public nor private realm), who in some cases do not respect national labor laws nor environmental standards. The cooperativistas have great influence in the MAS government, and mining continues to be at the contentious center of environmental degradation and social conflict in much of the Andes. Yet the relationship is tense. Conflicts over a new labor law recently pit the cooperativistas against the government, leading to the death of a vice-minister. Against this backdrop, Bolivia's vision for the development of a national lithium industry is full of grandiose dreams.

Lithium is used to make the batteries that power twenty-first-century consumer practices. The chemical element is a key component to smart phones and computers, and has become integral to the growing energy storage industry that has developed around renewables and electric cars. Because of this, powerful global players are investing billions of dollars in lithium's future. Some speculate that lithium car battery sales could soon jump from $\$ 100$ million per year to $\$ 103$ billion per year. If so, the countries that possess lithium are poised to become major players in the global economy. Bolivia, which is home to 70 percent of the world's lithium reserves, stands squarely at the center of this potential boom.

More specifically, the country's Uyuni salt flats contain more lithium carbonate reserves than anywhere else in the world. Recently, Evo Morales declared that by exploiting lithium in a 400 square kilometer area, Bolivia would have "enough national revenue to maintain ourselves for the next century." The government plans to invest $\$ 995$ million in the development of the lithium industry between 2015 and 2019 and processing capacity development. It is the second largest state investment after the \$1 billion USD that was funneled into the gas sector six years ago. South Korea, Russia, China, Brazil, and most significantly, Japan and France, are beginning to invest in the industry as well.

Here, like gas -and unlike more conventional mining sectors- the Bolivian state is poised to take a central role. Government responsibility for planning and carrying out lithium development lies with the public mining company, COMIBOL. Key decisions must be made and approved by Bolivia's Ministry of Mining and Metallurgy. And the state's current plan for the various phases of its lithium extraction has included an investment of just under $\$ 6$ million USD for the development of a "pilot plan" that will test the best methods for 
extracting lithium-rich brine out from under the crust of the salt flats and then separating it into its distinct and marketable parts. According to Rebecca Hollander and Jim Shultz, the government then aims to construct a much larger industrial-scale plant capable of producing up between 30,000 and 40,000 metric tons of lithium carbonate per year. The last phase of the project will be the production of marketable lithium compounds, something that is expected to occur alongside foreign investors and partners.

It is not clear exactly what labor regimes will look like in the lithium industry, although as with the gas industry, stratification is likely along lines of technical expertise, as well as racial and ethnic lines. Equally uncertain are the markets and contractual arrangements that will structure the relationship between the state and foreign capital. And, as with big agro, it is not yet clear what impact these activities will have on local economies that rely on smallscale agricultural production of things like quinoa, the grazing of llamas, and tourism.

One thing is clear: lithium development will have significant socioenvironmental impacts. The salt flats where lithium is so abundant are located in some of the country's most arid territory. In these places, access to water is key for the local communities and their livelihoods and is already in short supply. In Chile's Atacama salt flats, mining has long consumed, contaminated, and diverted scarce water resources away from local communities. Given that industrialization plans for the region will stress an already over-tapped supply of water, the obvious question is: What is the government's plan to bring in required water? To date, the Morales government has provided no answers to this question.

Similarly, the contamination of air, water, and soil is also a major concern. Large quantities of toxic chemicals will be needed to process the 30,000 to 40,000 tons of lithium that are produced annually. Chemicals can possibly escape via leaching. The potential of chemical spills also poses a danger to communities and the ecosystem as a whole, and it is currently unclear how equipped Bolivian environmental regulators are for to guarding against such damages. With appropriate political space for public concerns, lithium might be developed in a relatively responsibly manner. However, if the government's fiscal needs overshadow social and environmental concerns, we can expect a much less revolutionary approach to this massive industrial project. 


\section{The Uncertain Future of Progressive Change}

When gas and water were privatized in the late 1990s and 2000s, the United States still represented the epicenter of global economic power. Bolivia's neoliberal regimes, particularly during the era of Gonzalo Sánchez de Lozada, took steps to position Bolivia more firmly into the U.S. orbit. Yet the global economic landscape today is much more varied. U.S. military activities continue to extend their reach into the region, and U.S. friendly regimes appear to be reassuming power in neighboring Brazil, Paraguay, and Argentina, among other places. As the U.S. occupies itself with Mexico and Central America, pushes for regime change in Venezuela, and struggles to secure key alliances in the region through the Trans-Pacific Partnership (TPP) and the right-wing business class of the Southern Cone, its old point of leverage for intervention in Bolivia -the drug war- has been weakened. In addition, Bolivia's turn toward Brazil and Argentina, as well as its opening to Chinese credit and investment, as well as flirting with Russian gas companies and Iran, Bolivia has reconfigured its relationship with the United States, which now plays a secondary role, for the moment. Even so, throughout the last decade and a half, the power of foreign capital in Bolivia has persisted. Ironically, while the Morales government has gone further than any other government in speaking of a new economic model, many argue that the MAS has done more than any prior government to deepen the reach of capitalism in the country.

Bolivia's beleaguered NGOs -struggling to survive amid the resurgence of the state-have focused their efforts on critiquing the mining and hydrocarbons industries, particularly as they impact nature and the rights of local communities. A number of movements have fractured along these lines, some supporting MAS and extraction, and others positioning themselves against one or another specific project. Yet these issue-specific positionings lend themselves to curious articulations. One is asked to be for or against gas exploration, for instance, yet often this is code for whether one is for or against Evo Morales and the MAS. Rather than drawing simplistic positions, we would do well to engage further with movements and organizations that have worked diligently to delve into the specifics of distinct economic sectors and the envisioning of political and economic alternatives.

In the area of gas and energy development, we can hope for a deepening of the push for renewable energy and a slow braking of the accelerated monetization of underground gas reserves. With climate change a pressing reality -and with water scarcity already at a crisis point- the disturbing talk 
about fracking in Bolivia must certainly be a terrain for critical struggle. Moreover, the turn toward hydropower along the Bolivia-Brazil border and in the northern area of La Paz seems short sighted. At what point does the conversion of Bolivia into the "energetic heart" of America mean the creation of environmental disaster? State efforts at large-scale energy production for export may have a progressive edge, but they have offered little in terms of providing new models for regional energy production and redistribution.

In the realm of land reform in Bolivia's eastern lowlands, new land and food movements are likely to emerge as the limits of the country's agroindustrial model confront the limits of urban marginalization. The MAS is unlikely to challenge landowner power in the east after the 2015 referendum defeat that prevents Evo Morales from running again for president. Whether and how NGO efforts might support new agrarian movements that can place pressure on the government to stop subsidizing capital, both foreign and domestic, remains to be seen. The state has done little to help smaller producers, but how might state credit and technical support be redirected to smaller and medium-scale farmers? Here the power of the soy and agroindustrial complex looms large. At the moment, there is no broad-based agrarian movement that might bridge the divide between peasants, lowland indigenous peoples, and highland colonizadores (those who have migrated and colonized lands in the East) -let alone movements that might bridge urbanrural divides by linking issues like infrastructure and access to critical resources in the periphery of Santa Cruz to rural resource scarcity and crisis.

Finally, in the country's mining communities, the need for decent livelihoods has been thrown into conflict with the real threats of poisoned land and water. To be against mining altogether may give one a feeling of righteousness but has little political purchase in Bolivia. Yet organizations have pushed for alternatives -demanding everything from more local control to enforceable environmental regulation to state-funded cleanups of toxic lands and rivers. Certainly, there will be times and spaces for outright opposition to new projects, and indeed, as the Bolivian right has recently come to power with the forced resignation of Morales in November 2019, the struggle is likely to crystallize around these points. During this interim period, we have seen the total collapse of MAS as a political party and the rise of the Rightwing regime which will continue to expand upon these extractivist dreams. The fears of expanding soy production in the East, more gas extraction, displacements of indigenous communities, and further degradation of the Amazon are all on the horizon in a post-MAS climate. 


\section{Works Cited}

BIF (Bolivia Information Forum). 2016. "Ten Years on: The Morales Government in Perspective." Bulletin no. 35.

DIAZ-STRUCK, Emilia. 2017. Panama Papers investigation reveals Bolivia's offshore connections. [https://www.icij.org/blog/2017/10/panamapapers-investigation-reveals-bolivias-offshore-connections/] downloaded Dec. 10, 2019.

FABRICANT, Nicole. 2012. Mobilizing Bolivia's Displaced: Indigenous Politics and the Struggle over Land. Chapel Hill, NC: University of North Caroline Press.

FARTHING, Linda. 2019. "An Opportunity Squandered? Elites, Social Movements and the Government of Evo Morales." Latin American Perspectives 224.46 (1): 212-229.

FORBES. 2015. "Santa Cruz: Bolivia's booming business capital." [https://custom.forbes.com/2015/09/28/santa-cruz/] downloaded Dec. 10, 2019.

GUSTAFSON, Bret. Forthcoming. "Decolonization, Sort of? Indigeneity and Gas in Southern Bolivia." Remediating Cartographies of Erasure: Anthropology, Indigenous Epistemologies, and Global Imaginaries. Bernard Perley, ed. Lincoln, NE: University of Nebraska Press.

---. 2012. "Fossil Knowledge: Industry Strategy, Public Culture, and the Challenge for Critical Research." Flammable Societies: Studies on the Socio-Economics of Oil and Gas. John-Andrew MacNeish and Owen Logan, eds. London: Pluto Press. 311-334.

HOLLANDER, Rebecca and Jim Shultz. 2017. "Bolivia and Its Lithium: Can the 'Gold of the $21^{\text {st }}$ century' lift a nation out of poverty?"

[http://upsidedownworld.org/archives/bolivia/bolivia-and-its-lithiumcan-the-gold-of-the-21st-century-lift-a-nation-out-of-poverty/] downloaded Dec. 10, 2019.

LANGMAN, Jimmy. 2008. "The Global Pesticide Pushers in Latin America." NACLA Report on the Americas [https://nacla.org/article/globalpesticide-pushers-latin-america] downloaded Dec. 10, 2019.

McKAY, Ben. 2017. The Politics of Control: New Dynamics of Agrarian Change in Bolivia's Soy Complex. PhD. Dissertation. Erasmus University Rotterdam.

---. $\quad$ and Gonzalo Colque. 2016. "Bolivia's Soy Complex: The Development of 'Productive Exclusion'." The Journal of Peasant Studies 43(2): 583610.

PACHECO, Pablo. 2006. "Agricultural Expansion and Deforestation in Lowland Bolivia: The Import Substitution Versus the Structural Adjustment Model." Land Use Policy 23(3): 205-225.

REVETTE, Anna C. 2016. "This Time it's Different: Lithium Extraction, Cultural Politics and Development in Bolivia." Third World Quarterly 38(1): 149-168. 
URIOSTE, Miguel. 2012. "Concentration and Foreignization of Land in Bolivia." Canadian Journal of Development Studies / Revue canadienne d'études du développement 33(4): 439-457.

WRIGHT, Lawrence. 2010. "Lithium Dreams: Can Bolivia Become the Saudi Arabia of the Electric-Car Era?" The New Yorker. March 15.

[https://www.newyorker.com/magazine/2010/03/22/lithiumdreams] downloaded Dec. 10, 2019.

\section{$(\mathrm{cc}) \mathrm{EY}$}

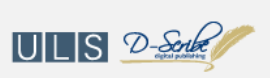

New articles in this journal are licensed under a Creative Commons Attribution 4.0 United States License.

This journal is published by the University Library System of the University of Pittsburgh as part of its D-Scribe Digital Publishing Program, and is cosponsored by the University of Pittsburgh Press. 